\title{
Comparative efficacy of different botanicals and chemical insecticides for controlling rice stem borer
}

\author{
A. K. Majlish ${ }^{1}$, M. M. Uddin ${ }^{2 *}$, M. Jahan ${ }^{2}$ and M. M. Rahman ${ }^{3}$ \\ Department of Entomology, Bangladesh Agricultural University Mymensingh-2202, Bangladesh \\ *Email: mahirbau@yahoo.com
}

\begin{abstract}
An experiment was carried out in the field laboratory, Department of Entomology, Bangladesh Agricultural University to find out the efficacy of different botanicals and chemical insecticides against rice stem borer during the period from July to December 2013. The treatments included Neem oil, Mahogany oil, combination of Neem and Mahogany oil, Bishkatali leaf extract, Lantana leaf extract, combination of Bishkatali and Lantana leaf extract, Convoy 25EC, Biesterthoate 40EC, Biesteren $5 \mathrm{G}$ and Diatone 10G. The efficacies of treatments were evaluated based on the percent dead heart and white head resulted by rice stem borer infestation at vegetative and reproductive stages, respectively. The efficacies of treatments were varied significantly against the rice stem borers. Among the selected botanicals, Neem + Mahogany oil followed by Bishkatali leaf extract performed best and Bishkatali + Lantana followed by Lantana leaf extract and leaf extract were least effective to reduce dead heart as well as white head at different counting. Similarly, combination of Neem and Mahogany oil gave the maximum yield among the selected botanicals. Diatone $10 \mathrm{G}$ showed the best performance to reduce percent dead and white head among the selected chemical insecticides and gave maximum yield among different chemical insecticides. On the other hand, Convoy 25EC was the least effective to control dead heart and white head infestation with yield. Therefore, Neem + Mahogony oil and Diatone $10 \mathrm{G}$ were the best to control rice stem borer and to increase the yield of rice grain.
\end{abstract}

Keywords: Efficacy, Botanical, Chemical insecticide, Control, Rice, Stem borer

\section{Introduction}

Rice (Oryza sativa L.) is one of the most important cereal crops in the world, providing food for nearly half of the global population (Khush, 1997; Lu, 1998 and FAO, 2004). Rice is grown on over 145 million hectares in more than 110 countries. It occupies one fifth of the world crop land under cereal (Pathak and Khan, 1994). It is the staple food for more than 65 percent of the world population (Mathur et al., 1999).

Rice is the staple food of Bangladesh, about $90 \%$ of its population depends on rice for their food intake (BBS, 2013). Among the leading rice growing countries of the world, Bangladesh ranks fourth in both area and production (Das, 2005). About $75 \%$ of the total cropped area and over $80 \%$ of the total irrigated area is planted to rice. However, its demand is rapidly increasing with the increase of population (Virmani et al., 1997). Thus, continuous efforts are giving to obtain sustainable increase in rice production. On the other hand, insect pest is one of the major constrain to the successful rice production (Waddington et al., 2010) have risen many folds during these decades which may loss about $30-40 \%$ yield (Heinrichs et al., 1994). Among the insect pests of rice, stem borers (Scirpophaga incertulas and Scirpophaga innotata) are the serious pests of rice in South and South East-Asia (Rehman et al. 2002). Among the borers, rice yellow stem borer (RYSB), S. incertulas is the most important insect pest of rice in Bangladesh (Islam and Hasan, 1999). RYSB attacks crop right from the seedling stage till harvest and cause enormous loss of affected tillers (Dillon, 2011).

In the vegetative stage of the rice plant, young larvae feed on the leaf sheath and ultimately bore into the stem and feed inside. This prevents the central leaf whorls from unfolding, causing them to turn brownish and die, bringing about the condition known as "dead hearts." In the infested plants, panicles may not emerge at all (Atwal, 1976). During the reproductive stage of the rice plant, the stem borers' larvae cut the growing parts leading to the condition known as "White heads" (Gupta and O'Toole, 1986) do not produce grain and become conspicuous (Atwal, 1976; Satpathi et al., 2012).

Farmers depend upon a great deal of insecticide applications, even though a lot of insecticide applications are not effectual (Sarwar et al., 2005). Moreover, the indiscriminate use of insecticides have resulted in a number of undesirable side effects such as the emergence of resistant species of insects, undesirable effects on non-target organisms including the natural enemies of the target pests and 
induced resurgence of the target pest and outbreak of secondary pest (Heinrich, 1994). Excessive and indiscriminate use of insecticides not only affects the pest but also becomes a major source of human health hazard, environmental pollution, fish toxicity and deleterious on predators, parasitoids, pathogens and pollinators (Guan-Soon, 1990; Debach and Rosen, 1991 and Phillips et al., 1990). On the other hand, botanicals having broad-spectrum insecticidal properties can be incorporated in integrated pest management programs which can greatly decrease the use of conventional pesticides or can be used in rotation or in combination with other insecticides for mitigating complications produced in conventional chemical insecticides application (Khater, 2012).

Simultaneously, judicial and appropriate use of insecticides is essential for the successful management of stem borers and to sustain increased productivity of rice. Based on the aforesaid issues, the present research was carried out to evaluate the efficacy of different botanicals and chemical insecticides against the infestation caused by rice stem borer and find out the effect of different botanicals and chemical insecticides on the rice yield.

\section{Materials and Methods}

The experiments were conducted in the Entomology Field Laboratory, Department of Entomology, Bangladesh Agricultural University, Mymensingh during the period of July to December 2013. At first the land $\left(123.75 \mathrm{~m}^{2}\right)$ was prepared by ploughing and cross ploughing followed by laddering. All stubbles and weeds were removed carefully. The land was divided into 3 blocks and each block was divided into 11 plots of $2 \mathrm{~m}^{2}$ maintaining $0.5 \mathrm{~m}$ spacing in between two plots and $0.25 \mathrm{~m}$ from border to facilitate different intercultural operations.10 treatments (Table-1) and a control were laid out in a Randomized Complete Block Design (RCBD) with 3 replications of each.

Table 1. Details of different treatments used in the experiment

\begin{tabular}{c|l|lc}
\hline Treatments & \multicolumn{1}{|c}{ Plant Extracts /Chemicals } & Scientific /Chemical Name & Dose \\
\hline $\mathrm{T}_{1}$ & Neem oil & Azadirachta indica & $20 \mathrm{ml} / \mathrm{L}$ \\
$\mathrm{T}_{2}$ & Mahogany oil & Swietenia macrophylla & $20 \mathrm{ml} / \mathrm{L}$ \\
$\mathrm{T}_{3}$ & Combination of Neem and Mahogany oil & $20 \mathrm{ml} / \mathrm{L}$ \\
$\mathrm{T}_{4}$ & Bishkatali leaf extract & Polygonum hydropiper & $100 \mathrm{ml} / \mathrm{L}$ \\
$\mathrm{T}_{5}$ & Lantana leaf extract & Lantana camara & $100 \mathrm{ml} / \mathrm{L}$ \\
$\mathrm{T}_{6}$ & Combination of Bishkatali and Lantana leaf extract & $100 \mathrm{ml} / \mathrm{L}$ \\
$\mathrm{T}_{7}$ & Convoy 25EC & Quinalphos & $25 \mathrm{ml} / 10 \mathrm{~L}$ \\
$\mathrm{~T}_{8}$ & Biesterthoate 40EC & Dimethoate & $22.5 \mathrm{ml} / 10 \mathrm{~L}$ \\
$\mathrm{~T}_{9}$ & Biesteren 5G & Carbofuran & $9.9 \mathrm{Kg} / \mathrm{ha}$ \\
$\mathrm{T}_{10}$ & Diatone 10G & Diazinon & $17 \mathrm{Kg} / \mathrm{ha}$ \\
$\mathrm{T}_{11}$ & Control (Untreated) & & - \\
\hline
\end{tabular}

Rice variety, BR11 was used for the experiment and seedlings were collected from the Central Farming System of BAU. After transplanting, all recommended agronomic practices along with fertilizers were applied. For the preparation of Lantana (Lantana camara) and Bishkatali (Polygonum hydropiper) extract, leaves were cut into small pieces and mixed with $2 \%$ formalin solution and were extracted using an electric mixer. On the other hand, Neem and Mahogany oil were collected from Mati Corporation Ltd, Uttara, Dhaka. These oils were diluted as required with adding water and $1 \mathrm{mg}$ detergent was mixed in each one liter solution. The treatments were applied with the help of a hand-operated sprayer at 10 days interval started at 45 days of transplanting for counting dead heart and at 10 days after panicle initiation for counting white head. Care was taken to avoid spray drift on adjacent plants. The spraying was done in such a way that the spray droplet did not coalesce and drain down in the soils and whole plot was thoroughly covered by spray material. After spraying each treatment with designed dose, the sprayer was washed and cleaned properly. The control plots were not sprayed with anything. All of the treatments were applied for three times, two applications were done at the tillering stage and the last application was done at the panicle initiation stage. Before each application total number of dead heart (at vegetative stage), white heads (at reproductive stage) and total number of tillers were counted for each plot. Pre- 
treatment data were also recorded before application of botanicals and synthetic insecticides for better understanding. The percentage dead hearts and white heads were computed by using the Abbott's (1925) formula. The formula is-

$$
\begin{aligned}
& \% \text { Dead heart }=\frac{\text { No. of dead heart }}{\text { No. of total tiller }} \times 100 \\
& \% \text { White head }=\frac{\text { No. of white head }}{\text { No. of total tiller }} \times 100
\end{aligned}
$$

Data for yield per plot were also recorded after harvesting of rice. The recorded data were compiled and tabulated for statistical analysis. Analysis of variance was done with the help of computer package MSTAT-C. The mean differences among the treatments were adjudged as per test with Duncan's Multiple Range Test (DMRT) and Least Significant Difference (LSD) when necessary.

\section{Results and Discussion}

\section{Efficacy of different botanicals and chemical insecticides on percent dead heart}

Data on dead heart from different plots at different times were calculated as percentage, analyzed statistically and presented in the Table 2. Data revealed that, all treatments were efficient enough to reduce percent dead heart comparing to the untreated control plot.

\begin{tabular}{|c|c|c|c|}
\hline Treatments & \multicolumn{3}{|c|}{$\%$ dead heart } \\
\hline Botanicals and Chemicals & $\begin{array}{l}\text { Pre-treatment } \\
\text { (45 DAT) }\end{array}$ & $\begin{array}{c}\text { At } 1^{\text {st }} \text { counting } \\
\text { (55 DAT) }\end{array}$ & $\begin{array}{c}\text { At } 2^{\text {nd }} \text { counting } \\
\text { (65 DAT) }\end{array}$ \\
\hline Neem oil & $0.56 \mathrm{e}$ & $0.82 \mathrm{f}$ & $1.13 \mathrm{e}$ \\
\hline Mahogany oil & $1.10 \mathrm{c}$ & $1.16 \mathrm{~d}$ & $1.56 \mathrm{~d}$ \\
\hline Neem and Mahogany oil & 0.60 ef & $0.62 \mathrm{~g}$ & $0.73 \mathrm{f}$ \\
\hline Bishkatali leaf extract & $0.63 e f$ & $0.73 \mathrm{gf}$ & $0.83 \mathrm{e}$ \\
\hline Lantana leaf extract & $1.37 \mathrm{~b}$ & $1.47 \mathrm{~b}$ & $1.90 \mathrm{c}$ \\
\hline Bishkatali and Lantana leaf extract & $0.86 c$ & $1.35 \mathrm{c}$ & $1.88 \mathrm{c}$ \\
\hline Convoy $25 \mathrm{EC}$ & $1.49 \mathrm{~b}$ & $1.77 \mathrm{~b}$ & $2.02 \mathrm{~b}$ \\
\hline Bisterthoate 40EC & $0.86 \mathrm{~d}$ & $0.94 \mathrm{e}$ & $1.08 \mathrm{e}$ \\
\hline Biesteren $5 G$ & $0.82 d$ & $1.00 \mathrm{e}$ & $1.11 \mathrm{e}$ \\
\hline Diatone 10G & $0.40 f$ & $0.56 \mathrm{~g}$ & $0.63 \mathrm{~g}$ \\
\hline Control & $2.42 \mathrm{a}$ & $2.67 \mathrm{a}$ & $2.95 \mathrm{a}$ \\
\hline $\mathrm{LSD}_{0.05}$ & 0.152 & 0.107 & 0.093 \\
\hline
\end{tabular}

Table 2. Percent dead heart under different treatments at two counting

Means followed by the same letter in a column are not significantly different, DAT = Days after transplanting

Pre-treatment dead hearts were recorded before the application of treatments. Pre-treatment dead heart count aimed to determine the availability of rice stem borer, extent of damage caused by pest and effectiveness of treatments to control the target insect. At $1^{\text {st }}$ counting, minimum infestation was recorded in Diatone 10G treated plots (0.56\%) which were about four times lower than untreated control plots. On the other hand, maximum infestation was occurred in Convoy 25EC treated plots (1.77\%) although it was almost two times lower and significantly effective comparing to untreated plots. The percent dead heart in the combination of Bishkatali and Lantana leaf $(1.35 \%)$ extract treated plots were found a bit less and significantly better than Convoy 25EC treated plots. Mahogany oil (1.16\%) was little bit better than combination of Bishkatali and Lantana leaf extract and they were significantly effective than the untreated control plots. However, Bishkatali leaf extract $(0.73 \%)$, combination of Neem and Mahogany oil $(0.62 \%)$, Biesterthoate 40EC (0.94\%) and Biesteren 5G (1.00\%) were statistically similar and significantly effective. At $2^{\text {nd }}$ counting, the lowest infestation was also recorded in Diatone $10 \mathrm{G}(0.63 \%)$ treated plots which were about four times lower than untreated control plots but a little more than combination of Neem and Mahogany oil treated plots $(0.73 \%)$. In contrast, the highest infestation was found in the Convoy 25EC 
treated plots (2.02\%) although it was almost half and significantly effective comparing to untreated plots. The percent dead heart in the Lantana leaf extract (1.90\%) and combination of Bishkatali and Lantana leaf extract (1.88\%) treated plots were found a little less than Convoy 25EC treated plots and these were significantly better than Convoy. However, Neem oil (1.13\%), Biesterthoate 40EC (1.08\%), and Biesteren 5G (1.11\%) were comparatively better than Mahogany oil (1.56\%) while these three were observed moderately effective among the tested botanicals and chemical insecticides in the experiment.

From the above discussions, maximum control of \% dead heart infestation was done by Diatone 10G. On the other hand, Convoy 25EC was comparatively less effective to reduce \% dead heart caused by the stem borer infestation. This result was different from the finding of Misra et al. (2004). They stated that Quinalphos (same chemical group of Convoy) might be effective in reducing dead heart up to 50.0 $65.2 \%$ depending on the appropriate time of application. In the present study overall performance of botanicals and synthetic insecticides showed their differences. Among the chemical insecticides Diatone $10 \mathrm{G}$ caused the highest reduction of dead heart symptom over control. Similarly among the botanicals, combination of neem oil \& mahogany oil provided the highest efficacy in reducing dead heart caused by rice stem borer. These findings are similar with the findings of following authors. Rahman (2013) found that chemicals and botanicals caused significant difference in their effects against yellow stem borer. Among the chemicals Dursban 20EC caused highest reduction in dead heart symptom and in case of botanicals Neem extracts caused highest reduction in the symptom. Ogah et al. (2011) reported that neem seed kernel and synthetic insecticide (Carbofuradan) showed significant $(p<0.01)$ reduction of stem borers damage (number of dead hearts) compared to untreated check. Dhuyo and Soomro (2007) conducted a field experiment using neem seed kernel extract against rice yellow stem borer and found that comparable lowest dead heart was present in comparison to untreated control. Similarly Islam et al. (2013) did a field experiment using botanicals and chemical insecticides and found that Fipronil (Neema 50SC) and neem extract caused $51.89 \%$ and $38.38 \%$ reduction of dead heart respectively.

\section{Efficacy of different botanicals and chemical insecticides on percent white head}

In case of percent white head all treatments were found significantly effective comparing to the untreated control plots (Table 3). Plots treated with Diatone 10G started minimum white head (0.07\%) which was far lower than the untreated controlled plots. A bit more white head was found in combination of Neem and Mahogany oil treated plots and Bishkatali leaf extract sprayed plots $(0.13 \%)$ than Diatone $10 \mathrm{G}$ treated plots, although these were statistically identical with Lantana leaf extract (0.17\%) and Biesteren 5G $(0.17 \%)$ treated plots. More or less similar white head infestations were recorded in the Bisterthoate 20EC and Mahogany oil treated plots $(0.20 \%$ and $0.23 \%$ respectively) which were slightly less than Neem oil treated plots (0.28). On the other hand, maximum infestation was occurred in the Convoy 25EC treated plots (0.35\%) followed by combination of Bishkatali and Lantana leaf extract sprayed plots (0.33\%) but these were significantly better than untreated plots.

Table 3. Percent white head under different treatments at 75 DAT

\begin{tabular}{|c|c|}
\hline $\begin{array}{c}\text { Treatments } \\
\text { Botanicals and Chemical Insecticides }\end{array}$ & $\begin{array}{l}\text { \% white head } \\
\text { (75DAT) }\end{array}$ \\
\hline Neem oil & $0.28 \mathrm{bcd}$ \\
\hline Mahogany oil & $0.23 b c d e$ \\
\hline Neem and Mahogany oil & $0.10 \mathrm{e}$ \\
\hline Bishkatali leaf extract & $0.13 \mathrm{de}$ \\
\hline Lantana leaf extract & $0.17 \mathrm{cde}$ \\
\hline Bishkatali and Lantana leaf extract & $0.33 b c$ \\
\hline Convoy 25EC & $0.35 b$ \\
\hline Biesterthoate 40EC & $0.20 \mathrm{bcde}$ \\
\hline Biesteren 5G & $0.17 \mathrm{cde}$ \\
\hline Diatone 10G & $0.07 e$ \\
\hline Control & $2.26 a$ \\
\hline $\mathrm{LSD}_{0.05}$ & 0.152 \\
\hline
\end{tabular}

Means followed by the same letter in a column are not significantly different, DAT = Days after transplanting 
From the above discussion, it was clear that Diatone $10 \mathrm{G}$ followed by combination of Neem oil and Mahogany oil and Bishkatali leaf extract were mostly effective to control stem borer infestation but Convoy 25EC followed by combination of Bishkatali and Lantana leaf extract were least effective. Misra et al. (2004) supported a part of our investigation as they stated that Quinalphos was not so effective for reducing white head. In the present research it was observed that all the used botanicals and synthetic insecticides showed their differences in overall efficacy. Among the synthetic insecticides in Diatone 10G treated plot significantly the lowest number of white head was found. Combination of neem oil \& mahogany oil followed the efficacy of Diatone $10 \mathrm{G}$ and the lowest number of white head caused by stem borer over untreated control. These findings are in agreement with the findings of Rahman et al. (2013). They reported that chemicals and botanicals caused significant difference in their effects against yellow stem borer. Among the chemicals Dursban 20 EC caused highest reduction in white head symptoms and in case of botanicals Neem extracts caused highest reduction in the symptom. Similarly Ogah et al. (2011) reported that neem seed kernel and synthetic insecticide (Carbofuradan) showed significant $(p<0.01)$ reduction of stem borers damage (number of white heads) compared to untreated control. Dhuyo and Soomro (2007) observed in a field experiment that comparable lowest dead heart was present in neem seed kernel extract treated plots in comparison to untreated control. They also suggested that neem seed kernel extract could be an alternative of chemical insecticide to control stem borers. Similarly Islam et al. (2013) did a field experiment using botanicals and chemical insecticides and found that Fipronil (Neema 50SC) and neem extract caused $65.05 \%$ and $58.08 \%$ reduction of dead heart respectively comparable to control.

\section{Efficacy of different botanicals and chemical insecticides on the grain yield of rice}

On harvesting, yield from individual plots was recorded from treated and as well as untreated plots were then analyzed and presented in the Table 4. There were wide ranges of variations observed for the yield in different plots.

Table 4. Yield under different treatments per plot

\begin{tabular}{l|c}
\hline \multicolumn{1}{c|}{ Treatments } & Yield (t/ha) \\
\hline Neem Oil & $7.45 \mathrm{bc}$ \\
Mahogany Oil & $7.35 \mathrm{bc}$ \\
Neem and Mahogany oil & $8.35 \mathrm{a}$ \\
Bishkatali leaf extract & $7.90 \mathrm{ab}$ \\
Lantana leaf extract & $7.25 \mathrm{bc}$ \\
Bishkatali and Lantana leaf extract & $7.95 \mathrm{ab}$ \\
Convoy 25 EC & $6.90 \mathrm{c}$ \\
Bisterthoate 40 EC & $7.35 \mathrm{bc}$ \\
Biesteren 5G & $7.95 \mathrm{ab}$ \\
Diatone 10G & $8.45 \mathrm{a}$ \\
\hline Control & $6.70 \mathrm{c}$ \\
LSD & 0.161 \\
\hline
\end{tabular}

Means followed by the same letter in a column are not significantly different, DAT = Days after transplanting

The highest yield was recorded in Diatone 10G (8.45 t/ha) and Combination of Neem and Mahogany oil (8.35 t/ha) which were much higher than untreated control plots but a little more than Bishkatali leaf extract $(7.90 \mathrm{t} / \mathrm{ha})$, combination of Bishkatali and Lantana leaf extract $(7.95 \mathrm{~kg} / \mathrm{plot})$ and Biesteren $5 \mathrm{G}$ (7.95 t/ha), Lantana leaf extracts $(7.90 \mathrm{t} / \mathrm{ha})$. On contrary, minimum yield was found in the Convoy 25EC (6.90 t/ha) which was significantly higher comparing to untreated control plots. However, Neem oil (7.45 t/ha), Mahogany oil (7.35 t/ha), Lantana leaf extract (7.25 t/ha) and Biesterthoate $40 \mathrm{EC}(7.35 \mathrm{t} / \mathrm{ha})$ were comparatively better than Convoy 25EC, although these three were observed moderately effective among the selected botanicals and chemical insecticides in the experiment. 
Considering the overall effect all treatments on the yield Diatone $10 \mathrm{G}$ was the best in increasing yield and among the botanicals mixture of neem oil and mahogany oil ranked the second position in case of yields increase which was significantly higher than untreated control. This result is partially supported by Rahman et al. (2013). They found that insecticides and botanicals reduced the infestation of yellow stem borer and thereby significantly influenced the yield performance of rice. They also reported that Dursban $20 \mathrm{EC}$ treated plot showed highest yield $(1.88 \mathrm{Kg} / \mathrm{plot})$ and neem extract treated plot showed the yield $1.40 \mathrm{Kg} /$ plot. Considering the efficacy and eco-friendly nature of neem extracts it could be considered as effective botanicals in successful management of the pest yellow stem borer of rice. Ogah et al. (2011) stated that neem seed kernel and synthetic insecticide (Carbofuradan) showed significant $(p<0.01)$ effect on reduction of stem borers damage compared to untreated check and also significantly $(p<0.05)$ increased number of productive tillers with resultant increase in grain yield than the control plots. Dhuyo and Soomro (2007) conducted a field experiment and reported that neem seed kernel extract produced comparable higher yield $\left(6,200 \mathrm{kgha}^{-1}\right)$ than the all other botanicals used and chemical insecticide karate $2.5 \mathrm{EC}$.

\section{Conclusion}

From the present study it was observed that the application of botanicals and chemical insecticides showed significant performance in reducing dead heart, white head and increasing of yield of rice in comparison to untreated control. Among the botanicals mixture of neem oil and mahogany oil and among the chemical insecticide Diatone $10 \mathrm{G}$ provided the best efficacy in reducing the stem borer infestation and increasing rice yield. On the basis of reduced borer infestation and high yield neem oil \& mahogany oil could be recommended as alternative of the insecticides in successful management of rice stem borer.

\section{References}

Abbott, W.S. 1925. A method for computing the effectiveness of an insecticide. J. Econ. Ento., 18: 265-676.

Atwal, A.S. 1976. Agricultural Pests of India and South East Asia. Kalyani Publishers, Ludhiana, India. pp. 153-160.

BBS (Bangladesh Bureau of Statistics). 2013. Monthly Statistics Bulletin. Bangladesh. June, 2013. pp. 71

Das, D.T. 2005. Rice in Bangladesh. BRRI, Gazipur, Dhaka.p. 5.

Debach, P. and Rosen, S. 1991. Biological Control of Natural Enemies. Cambridge University Press. 13p.

Dhuyo, A.R. and Soomro, N.M. 2007. Efficacy of plant extracts against yellow rice stem borer, Scirpophaga incertulas (Walk.) In Rice at Dokri, Sindh, Pakistan. Pakistan Entom., 29(1): 23-26

Dillon, M.K. 2011. Diagnostic symptoms and assessment of losses due to arthropod pests in crops. Advantages in Diagnosis of Arthropod Pests' Damage and Assessment of Losses. Department of Entomology, CCS Haryana Agricultural University, HISAR, 125004, pp 135-140.

FAO, Food and Agriculture Organization of the United Nations. 2004. The state of food security in the world, pp 30-31.

Guan-Soon, L. 1990. Overview of vegetables IPM in Asia. FAO Plant Protec. Bulle. 38(2): 73-78.

Gupta, S.P. and O'Toole, J.C. 1986. Upland Rice. A Global Perspective. International Rice Research Institute. Lospbanos, Laguna, Philippines.360p.

Heinrichs, E.A. 1994. Biology and Management of Rice Insects. Willey Eastern Ltd. London. p. 779.

Islam,M.S. Das,S. Islam, K.S. Rahman,A. Huda, M.N. and Dash, P.K. 2013. Evaluation of different insecticides and botanical extracts against yellow stem borer, Scirpophaga incertulas in rice field. Int. J. Biosci. 3(10): 117-125.

Islam, Z. and Hasan, M. 1999. Pests of rice in Bangladesh: Present management scenario and future challenges. Proc. First Agric. Cont. CARE Bangladesh Dhaka. pp. 90-98.

Khater, HF. 2012.Prospects of botanical biopesticides in insect pest management. Pharmacologia. 3(12):641-656.

Khush, G.S. 1997. Origin, dispersal, cultivation and variation of rice. Plant Mole. Biol. 35: 25-34.

Lu B.R.1998. Diversity of rice genetic resources and its utilization and conservation. Chinese Biodiversity 6: 63-72.

Mathur, K.C., Reddy, P.R., Rajamali, S. and Moorthy, B.T.S. 1999. Integrated pest management of rice to improve productivity and sustainability. Oryza, 36(3): 195-207. 
Misra, H.P. and Parida, T.K. 2004. Field screening of combination insecticides against rice stem borer and leaf-folder. Indian J. Plant Protec. 32(2): 133-135.

Ogah, E.O., Omoloye, A.A. Nwilene, F.E. and Nwogbaga, A.C. 2011. Effect of neem seed kernel extracts in the management of rice stem borers in the field in Nigeria. Nigerian J. Biotech. . 23:13- 21.

Pathak, M.D and Khan, Z.R. 1994. Insect pests of rice. International Rice Research Institute, P.O box 933, 10999, Manila, Philippines. pp 1-17.

Phillips, J.R., Graues, J.P and Luttecl, R.G. 1990. Insecticides resistance management. Pakistan J. Agri. Sci., 38: 3-4.

Rahman M.M. 2013. ECO-friendly management of rice yellow stem borer, Scirpophaga incertulas (Pyralidae: Lepidoptera) through reducing risk of insecticides. MS Thesis. Department of Entomology, Bangladesh Agricultural University, Mymensingh

Rehman, A., Inayatullah, C. and Majid, A. 2002. A descriptive model to predict the outbreaks of yellow stem borer, Scirpophaga incertulas. J. Agric. Res. Pakistan. 17(3): 282-289.

Sarwar, M., Ali A., Ahmad N. and Tofique M. 2005. Expediency of different botanical products intended for managing the population of rice stem borers. Proce. 25th Pakistan Conger. of Zoology, March 1-3, Sindh Agric. Uni., Tandojam. 25: 15-23.

Satpathi, C.R, Chakraborty, K., Shikari, D. and Acharjee, P. 2012. Consequences of feeding by yellow stem borer (Scirpophaga incertulas Walk.) on rice cultivar swarna mashuri (MTU 7029). World Applied Sciences Journal. 17: 532-539.

Virmani, S.S., Viraktamath, B.C., Casal, C.L., Toledo, R.S., Lopez, M.T. and Manalo, J.O. 1997. Hybrid Rice Breeding Manual, IRRI, Philippines. pp. 7-8.

Waddington, S.R., Li, X., Dixon, J., Hyman, G. and de Vicente, M.C. 2010. Getting the focus right: production constraints for six major food crops in Asian and African farming systems. Food Sec. 